\title{
VALIDITY AND RELIABILITY OF THE INDONESIAN VERSION OF SOCIAL MEDIA DISORDER (SMD) SCALE IN ADOLESCENT
}

\author{
Suzy Yusna Dewi ${ }^{1 *}$, Yunita Mansyah Lestari ${ }^{2}$ \\ ${ }^{1}$ Child and Youth Mental Health Installation, Soeharto Heerdjan Mental Hospital, Indonesia \\ ${ }^{2}$ Faculty of Medicine, Universitas Pembangunan Nasional Veteran Jakarta, Indonesia
}

*Correspondence email: suzyusna_dewi@yahoo.com

\begin{abstract}
Social media is popular in various circles, especially adolescents. Adolescents are the most vulnerable to be affected by technology. The excessive use of social media will make it difficult for adolescents who are addicted to social media. This study aims to adapt and assess the validity and reliability of the Social Media Disorder (SMD) questionnaire in Indonesian. The subjects of the study were adolescents aged 13-19 years and living in DKI Jakarta. Data were collected from $21^{\text {st }}$ April to $7^{\text {th }}$ June 2019 using consecutive and snowball sampling with a questionnaire via the Google Forms link. The number of research respondents was 30 and 207 respondents. The data were processed using SPSS 25 . The results were observed with the value of Cronbach's Alpha $=0,734$ and $r=0,513-0,614$, which means the Indonesian SMD questionnaire has good validity and reliability.
\end{abstract}

Keyword: Adolescents; Reliability; Social Media Disorder Scale; Validity

\section{INTRODUCTION}

Half of the population in Indonesia has used the internet $(54.68 \%) .{ }^{1}$ The increasing use of the internet and the widespread use of mobile applications has made social media more popular, especially for adolescents. In fact, in 2018, there were 3.169 billion people around the world actively using social media. ${ }^{2}$ While the number of active social media users in Indonesia in 2018 reached $48 \%$ of the population. The time spent by Indonesian citizens in using social media from various devices goes 3 hours, 23 minutes per day. This makes Indonesia ranked third in the world after the Philippines and Brazil. ${ }^{2}$

Social media is defined as online media that allows users to easily participate, share, and create content, including blogs, social networks, wikis, forums, and virtual worlds. ${ }^{3}$ If used properly, social media can make it easier for someone to live their lives. But sometimes, the use of social media has a negative impact, especially on adolescents. Adolescents often find it difficult to control themselves not to use social media to spend time using social media increases. Therefore adolescents are very susceptible to experiencing social media addiction.

According to Griffiths 2013, a person had addictive behavior if six components were fulfilled, consisting of salience, tolerance, mood modification, relapse, withdrawal, and conflict. $^{4}$

Social media addiction is when someone adds their usage time in a compulsive direction, and they have difficulty controlling themselves not to use social media. Social media addiction's adverse effects include reducing interpersonal communication skills, ${ }^{5}$ reducing social sensitivity, ${ }^{\text {six }}$ posting text, photos, and videos that refer to substance abuse, sex, and violence. ${ }^{7}$

At present, to establish social media addiction, there is a scale of SMD (social media disorder) created by Van den Eijnden et al. in 2016. They validated the specificity and sensitivity of 9 items in the IGD (Internet Gaming Disorder) criteria according to DSM 5 as a criterion in diagnosing social media addiction because SMD and IGD were considered part of internet addiction. ${ }^{8}$ SMD has nine standards, namely preoccupation, 
tolerance, withdrawal, persistence, displacement, problem, deception, escape, and conflict. In their research, the 9-item version of the SMD scale was a valid psychometric instrument in measuring social media addiction and was as accurate as the 27item version of SMD. This was evidenced by the confirmatory factor analysis test that matches a good model, reliable structural validity, appropriate internal consistency, adequate test-retest reliability, convergent validity, and good criteria. ${ }^{8}$

There are no valid and measurable instruments in Indonesia to determine whether a person is addicted to social media. Therefore, validity and reliability tests are needed from the Indonesian version of the SMD scale.

Validity is the appropriateness of an instrument in measuring what it wants to measure. Validity is divided into factor validity and item validity. Factor validity is used if there is one item consisting of more than one factor so that the measurement will be done to add the items in one factor and correlate it with the total score of all factors. While the validity of items is used to determine the correlation between each item with the overall score of the item, measured by correlating the score of each item with the total score of the item. ${ }^{9}$

In addition, measuring instrument reliability needs to be tested. Reliability tests are carried out to determine whether the measuring instrument used is reliable and remains consistent if the measurement is repeated. Measuring instruments are said to be reliable if the respondents answer each question item consistently over time. ${ }^{10}$

\section{MATERIAL AND METHODS}

The first carried out process was to request permission from the scale maker of SMD, namely Eijnden, Lemmens, \& Valkenburg, 2016. After obtaining permission, the SMD scale was translated into Indonesian. A sworn translator carried out this scale translation process. Furthermore, the scale that had been translated was examined by two experts in psychiatry to make adjustments to the words used on each item so that if there are different words will have a similar meaning. After that, the scale was translated back into English by the translation agency. The results of the translation were compared with the original version of the SMD scale. Furthermore, the Indonesian version of the SMD scale was tested on research subjects.

The data collection in this study was conducted two times, from 21st April to 7th June 2019. There were 30 respondents in the first data collection and 207 respondents in the second data collection. The research samples were those aged 13-19 years and living in DKI Jakarta. All respondents have received permission from parents to participate in this study. The research sampling method uses nonprobability sampling with consecutive and snowball sampling techniques. This technique was chosen so that the distribution and retrieval of data are easier and more scattered.

This research has passed the ethics of the Faculty of Medicine, Veteran National Development University, Jakarta. When collecting data, the researcher will emphasize ethical considerations. There were an informed consent form and permission sheet from the parents to become research respondents. Respondents followed this research based on the approvals of the respondents. Researchers will respect if the respondents refuse. The researcher maintains the confidentiality of the respondent's identity by not including the name, and the information provided by the respondents will be guaranteed by the researcher.

This study uses a social media addiction scale measurement tool obtained after the translation process into Indonesian from the original version, the English version of SMD. The social media addiction scale contains nine favorable questions with answers "yes" given a score of 1 and "no" given a score of 0 . Someone said to be addicted to social media if getting a score of 5 out of 9 criteria. Each question on a scale, researchers, put it into Google Forms, so researchers spread it using the Google Forms link. Researchers shared Google Forms links through social media 
such as Line, WhatsApp, Instagram, and Facebook.

The validity of each scale item was assessed using the Pearson Product Moment Correlation Test. Meanwhile, the reliability of the scale of social media addiction was assessed using Cronbach's Alpha coefficient. The program used to assess reliability and validity is SPSS (Statistical Package Service Solution) version 25.

\section{RESULT}

This research was conducted twice the spread of Google Forms. The data shows that most of the respondents are female. There were 30 adolescents (40\% male and $60 \%$ female) in the first data collection, and the second data collection was 207 respondents ( $19.8 \%$ male and $80.2 \%$ female). In the first data collection were female $(60 \%)$, aged 15 years and 18 years (30\%), with an equivalent

Table 1. Characteristics of Demographics

\begin{tabular}{|c|c|c|c|}
\hline Characteristics & $\begin{array}{l}\text { Total } \\
\mathbf{N}=\mathbf{3 0}\end{array}$ & Characteristics & $\begin{array}{c}\text { Total } \\
\mathbf{N}=\mathbf{2 0 7}\end{array}$ \\
\hline Gender & & Gender & \\
\hline Male & $12(40 \%)$ & Male & $41(19,8 \%)$ \\
\hline Female & $18(60 \%)$ & Female & $166(80,2 \%)$ \\
\hline Age (years) & & Age (years) & \\
\hline 13 & $1(3,3 \%)$ & 13 & $3(1,4 \%)$ \\
\hline 14 & $2(6,7 \%)$ & 14 & $12(5,8 \%)$ \\
\hline 15 & $9(30 \%)$ & 15 & $12(5,8 \%)$ \\
\hline 16 & $3(10 \%)$ & 16 & $29(14 \%)$ \\
\hline 17 & $2(6,7 \%)$ & 17 & $41(19,8 \%)$ \\
\hline 18 & $9(30 \%)$ & 18 & $51(24,6 \%)$ \\
\hline 19 & $4(13,3 \%)$ & 19 & $59(28,5 \%)$ \\
\hline Level of education & & Level of education & \\
\hline Middle School & $12(40 \%)$ & Middle School & $23(11,1 \%)$ \\
\hline High school & $7(23,3 \%)$ & High school & $94(45,4 \%)$ \\
\hline College & $11(36,7 \%)$ & College & $90(43,5 \%)$ \\
\hline \multicolumn{2}{|c|}{ Social Media Applications } & \multicolumn{2}{|c|}{ Social Media Applications } \\
\hline Youtube & $20(66,67 \%)$ & Youtube & $158(76,3 \%)$ \\
\hline FB Mesengger & $2(6,7 \%)$ & FB Mesengger & $10(4,8 \%)$ \\
\hline Facebook & $5(16,7 \%)$ & Facebook & $34(16,4 \%)$ \\
\hline Instagram & $27(90 \%)$ & Instagram & $190(91,8 \%)$ \\
\hline Twitter & $9(30 \%)$ & Twitter & $47(22,7 \%)$ \\
\hline Snapchat & $1(3,3 \%)$ & Snapchat & $24(11,6 \%)$ \\
\hline WhatsApp & $26(86,7 \%)$ & WhatsApp & $178(86 \%)$ \\
\hline Line & $25(83,3 \%)$ & Line & $133(64,3 \%)$ \\
\hline \multicolumn{2}{|c|}{ Time spent accessing social media } & \multicolumn{2}{|c|}{ Time spent accessing social media } \\
\hline Less than 3 hours & $3(10 \%)$ & Less than 3 hours & $22(10,6 \%)$ \\
\hline 3 to 6 hours & $18(60 \%)$ & 3 to 6 hours & $120(58 \%)$ \\
\hline More than 6 hours & $9(30 \%)$ & More than 6 hours & $65(31,4 \%)$ \\
\hline
\end{tabular}

level of junior high school education (40\%), used the Instagram application (90\%) and used social media for 3 to 6 hours $(60 \%)$. 
Table 2. Validity test results using Pearson Product Moment Correlation Test at a significance level of $5 \%$

\begin{tabular}{lcc}
\hline \multicolumn{1}{c}{ Criteria } & $\begin{array}{c}\text { R Counted } \\
\mathbf{N = 3 0}\end{array}$ & $\begin{array}{c}\text { R Counted } \\
\mathbf{N = 2 0 7}\end{array}$ \\
\hline Preoccupation & 0,622 & 0,540 \\
Tolerance & 0,616 & 0,614 \\
Withdrawal & 0,481 & 0,575 \\
Persistence & 0,897 & 0,558 \\
Displacement & 0,580 & 0,580 \\
Problem & 0,582 & 0,580 \\
Deception & 0,638 & 0,574 \\
Escape & 0,637 & 0,546 \\
Conflict & 0,645 & 0,513 \\
\hline
\end{tabular}

While the data collection of the two respondents at most were female $(80,2 \%)$, aged 19 years $(28.5 \%)$, had a high school education level $(45.4 \%)$, used the Instagram application (91.8\%), and used social media was 3 to 6 . hours (58\%). Demographic characteristics can be seen in table 1 .

Table 2 shows the correlation scores on each item with a total score in the range of 0.481-0.897 (30 respondents) and 0,5130,614 (207 respondents).

Table 3 shows the reliability coefficient of Cronbach's Alpha for each item ranges from 0.730 to 0.805 (30 respondents) and 0,700 to 720 (207 respondents). In contrast, the overall scale reliability value can be assessed in the Reliability Statistics so that a figure of 0.802 and 0,734 were obtained.

\section{DISCUSSION}

This study's validity test uses the Pearson Product Moment Correlation Test, which correlates each item's scores with the scale's total scores. According to Azwar in 2001, the questionnaire is valid if the items formed a single entity ${ }^{11}$. Pearson Product Moment is interpreted as valid if the Pearson correlation value on each item $>0,3 .^{12}$ In this study, the correlation score on each item with a total score were in the range of 0.481-0.897 and 0,513-0,614 (207 respondents). This shows the scale of valid social media addiction to measure the level of social media addiction.

This study's reliability test uses the Cronbach's Alpha formula by assessing each

Table 3. Reliability test results using the Cronbach's Alpha and Cronbach's Alpha If Item

\begin{tabular}{|c|c|c|}
\hline Criteria & $\begin{array}{c}\text { Cronbach's Alpha if item Deleted } \\
\qquad \mathbf{N}=\mathbf{3 0}\end{array}$ & $\begin{array}{l}\text { Cronbach's Alpha if item Deleted } \\
\qquad \mathrm{N}=207\end{array}$ \\
\hline Cronbach's & 0,802 & 0,734 \\
\hline \multicolumn{3}{|l|}{ Alpha } \\
\hline Preoccupation & 0,784 & 0,716 \\
\hline Tolerance & 0,785 & 0,700 \\
\hline Withdrawal & 0,805 & 0,709 \\
\hline Persistence & 0,730 & 0,710 \\
\hline Displacement & 0,790 & 0,707 \\
\hline Problem & 0,789 & 0,708 \\
\hline Deception & 0,779 & 0,708 \\
\hline Escape & 0,779 & 0,713 \\
\hline Conflict & 0,791 & 0,720 \\
\hline
\end{tabular}


item on a scale. The range of alpha coefficient values ranges from 0 (without reliability) to 1 (perfect reliability). ${ }^{13}$ According to Streiner, 2003 states that the instrument is said to be reliable if the Cronbach's Alpha reliability coefficient is more than $0.700 .{ }^{13,14}$ According to some experts in Budiastuti \& Bandur, 2018 the more statement items will have a higher reliability value. ${ }^{13}$ Based on the data above, the reliability coefficient of Cronbach's Alpha obtained for each item ranges from 0,730 to 0.805 (30 respondents) and 0,700 to 0,720 (207 respondents). This means that every item on the scale of social media addiction can rely on it.

\section{CONCLUSION}

The Indonesian version of the SMD questionnaire has good validity and reliability with Cronbach's Alpha $=0,734$ and $r=0,513$ 0,614 . So, this instrument can be used as early detection for screening social media disorder.

This research has several reasons: (1) in translating into Indonesian, and this study only uses one translator to make no comparison. (2) The number of research subjects is still limited. (3) The process of taking the subject using only Google Forms media has not been conducted interviews so that the understanding of the subject cannot be assessed more deeply. Further research is needed to get a better scale of the Indonesian version of Social Media Disorder.

\section{REFERENCES}

1. Asosiasi Penyelenggara Jasa Internet Indonesia [APJII] 2017, Profil Pengguna Internet Indonesia, Indonesia, https://apjii.or.id/survei2017

2. Global Web Index 2018, Social Global Web Index's flagship report on the latest trends in social media, https://www.globalwebindex.com/hubfs /Downloads/Social-H2-2018-report.pdf

3. Cahyono, AS 2016, Pengaruh Media Sosial terhadap Perubahan Sosial Masyarakat di Indonesia, Jurnal Publiciana, Vol 1 No 9, pp.140-157, http://jurnal-unita.org/index.php/ publiciana/article/view/79
4. Simsek, A, Elciyar, K, Kizilhan, T 2019. A Comparative Study on Social Media Addiction of High School and University Students, Vol. 10, No. 2, pp.106-119, https://doi.org/10.30935 /cet.554452

5. Rahman, SHA 2014, Can't Live without my FB, LoL: The Influence of Social Networking Sites on the Communication Skills of TESL Students, Procedia Social and Behavioral Sciences, Vol 134, pp.213-

219,https://doi.org/10.1016/j.sbspro.201 4.04.241

6. Zelsdorf, E 2014, Social Media, Social Skills, and Well-Being: The Impact of Web 2.0 Summary of Dissertation Research, Doi: 10.13140/2.1.3297.5362.

7. Reid, D, Weigle, P 2014, Social Media Use among Adolescents: Benefits and Risks, Adolescent Psychiatry, Vol 4, pp.73-80, Doi: 10.2174/221067660402 140709115810

8. Van den Eijnden, RJ, Lemmens, JS, Valkenburg, PM 2016, The Social Media Disorder Scale: Validity and psychometric properties, Computers in Human Behavior, Vol. 61, pp.478-487, https://doi.org/10.1016/j.chb.2016.03.03 8

9. Dewi, DANN 2018, Modul Uji Validitas dan Reliabilitas, Universitas Diponegoro, https://www.researchgate. net/publication/328600462_Modul_Uji_ Validitas_dan_Reliabilitas

10. Janti, S 2014, Analisis Validitas dan Reliabilitas dengan Skala Likert terhadap Pengembangan S1/T1 dalam Penentuan Pengambilan Keputusan Penerapan Strategic Planning pada Industri Garmen, Prosiding Seminar Nasional Aplikasi Sains \& Teknologi (SNAST) 2014, pp.155-160, http://repository.akprind.ac.id/repo/conf erence-proceedings/analisis-validitasdan-reliabilitas-dengan-skala-likertterhadap-pengemb

11. Sugiyono, 2013, Metode Penelitian Pendidikan Pendekatan Kuantitatif, Kualitatif, dan $R \& D$, Bandung: Alfabeta. 
12. Rahayuni, K \& Yunus, M 2019, Analisis Psikometri Validitas dan Reliabilitas Kuesioner Athletic Stress Inventory-28 (CSAI-28) dalam Bahasa Indonesia, Universitas Negeri Malang, https://www.researchgate.net/publicatio n/331647255_analisis_psikometri_valid itas_dan_reliabilitas_kuesioner_athletic _coping_stress_inventory-28_csai28_dalam_Bahasa_Indonesia

13. Budiastuti, D, Agustinus B 2018, Validitas dan Reliabilitas Penelitian : Dilengkapi analisis dengan nvivo, spss dan amos, Jakarta: Mitra Wacana Media, http://eprints.binus.ac.id/34441/1/2018_ validitas\%20dan\%20reliabilitas\%20pen elitian.pdf

14. Yusup, F 2018, Uji Validitas dan Reliabilitas Instrumen Penelitian Kuantitatif, Juranl Tarbiyah: Jurnal Ilmiah Kependidikan, Vol 7, No.1, pp.17-23, e-ISSN: 2548-8376, https://jurnal.uinantasari.ac.id/index.php/jtjik/article/vie $\mathrm{w} / 2100$ 